\title{
SANSI, Roger. Art, anthropology and the gift. London: Bloomsbury, 2015. 188 p.
}

\author{
Guilherme Giufrida* \\ *Universidade Estadual de Campinas - Campinas, SP, Brasil \\ Doutorando em Antropologia Social \\ giufridagp@gmail.com
}


Arte e antropologia questionam a modernidade e o Ocidente aos quais estão também associadas. Para Roger Sansi, ambas se preocupam, no sentido teórico e prático, com a política da representação. Não compartilham simplesmente um interesse por "outras culturas", mas "o objetivo de quebrar com a expertise, a erudição e a autoridade acadêmicas, para serem elas mesmas 'primitivas'" (p. 140, tradução minha).

O livro Art, anthropology and the gift é uma análise estrategicamente construída por uma colagem de conexões entre arte e antropologia a partir do índice da dádiva. O objetivo é indagar qual a extensão desse e de outros conceitos caros a antropólogos - como Marcel Mauss, Marilyn Strathern e Alfred Gell na arte. "Em vez de perguntar se eles estão usando a antropologia corretamente, pode-se perguntar para o que eles a utilizam" (p. 37, tradução minha). A obra situa os temas da relação e da participação na arte contemporânea, descreve alguns trabalhos e relê autores centrais desse campo, como o curador e crítico Nicolas Bourriaud.

O engajamento da arte com questões que são tradicionalmente do domínio das ciências sociais as conecta explicitamente. Há uma geração recente de artistas que definiram seu trabalho como "prática social" e cuja referência não é apenas história da arte, mas também teoria social e cultural, a antropologia em particular. $\mathrm{O}$ autor mostra como essa conexão é reiterada historicamente, relendo movimentos artísticos do século XX a partir do debate teórico e conceitual da antropologia. Além disso, discute como arte e antropologia (com foco nas teorias sobre a dádiva) travaram diálogos transversais, e se influenciaram mutuamente - mesmo que o interesse do livro não seja propriamente pelos mecanismos de tradução recíproca.

No Dadaísmo (movimento deflagrado na década de 1910), destaca a revisão da centralidade da autoria e o desenvolvimento do acaso. O próprio termo "dada" indica uma relação primitiva com a realidade, evidenciando a defesa do desaprendizado da civilização e da arte acadêmica e uma abertura para as coisas cotidianas. No Surrealismo (década de 1920), sublinha a relação de artistas com autores como Georges Bataille e Michel Leiris. Antropólogos e artistas desenvolveram no período pensamentos afins sobre magia, colagem, apropriação; além do filme de montagem, praticado tanto pelo cinema surrealista como no documentário etnográfico. Destaca também as relações entre práticas artísticas e antropológicas no Situacionismo (década de 1960), em síntese, o ato de deriva 
como proposição estética, especialmente na cidade, que passa a ser o próprio objeto da arte, extrapolando os espaços convencionais e subvertendo o cotidiano.

A crise da representação na antropologia, ligada à chamada crítica pós-moderna - da cultura como texto, sua descrição etnográfica como narrativa e a defesa da aproximação a métodos artísticos (especialmente literários) para se encontrar formas experimentais de (des)escrever, assumindo a arte de representar - foi por alguns denominada Virada Literária. Sansi propõe observá-la paralelamente à crítica da institucionalização das práticas artísticas e às argumentações por um maior engajamento com coletividades - a chamada Virada Etnográfica (década de 1980), em que artistas formulam seus trabalhos a partir de pesquisas com comunidades específicas, adotando inclusive a linguagem e os rituais das ciências sociais, especialmente o trabalho de campo.

O livro centra-se na produção artística contemporânea calcada em métodos participativos. Por exemplo, trabalhos em que o objetivo seja convidar pessoas para se reunir e conversar, construir relações sociais, quase sempre efêmeras hoje os museus de arte muitas vezes parecem "jardins comunitários" (p. 2). Os artistas se estabelecem mais como mediadores - pessoas que oferecem situações de troca - do que como criadores de objetos e materialidades. Produzir uma forma é, nesse sentido, estimular a reciprocidade através da proposição de uma situação de encontro, inventando um protocolo de trocas sem precedentes entre comunidades distantes, subvertendo contextos e instituições.

Os artistas apresentados não se assemelham àquele que domina técnicas usuais, mas, sim, ocupam-se em dirigir e organizar materiais produzidos por expectadores-participantes, criando aparatos físicos ou discursivos em que atores se expressam a partir dos dispositivos a que são convidados. $O$ evento artístico não está definido por uma mente que cria, mas é um encontro com o acaso, já que os projetos são permeáveis à indeterminação dos processos.

Sansi, em diálogo com Bourriaud (2009) em A estética relacional, defende que esse tipo de trabalho produz relações sociais e não objetos-commodities faz pessoas das coisas, e não coisas das pessoas. A arte é trabalhada como uma forma de vida e não como uma profissão, contrapondo-se à alienação do trabalho na produção industrial. Esse artista, mesmo que não seja um retrato da situação, é, para o autor, o seu estado potencial, pois exercita uma promessa de liberdade e de troca baseada na produção de relações especulando novos espaços, protótipos de uma vida compartilhada. 
Recupera também conceitos discutidos por Gell (1998) em Art and agency, autor que, segundo Sansi, elaborou uma teoria em sintonia com a arte de seu tempo, mais do que poderia imaginar. Em Gell, a arte não é tratada como representação, mas enquanto ação. Trabalhos de arte são objetificações da agência humana, uma rede (trap) de agências produtoras de efeitos (p. 53). Interessa menos o que a arte significa, e mais como a arte funciona.

O último capítulo do livro de Gell é uma breve incursão sobre Marcel Duchamp e a "mente estendida". Sansi ilumina esse ponto ao conectar o conceito de ready-made à rede de complexas intencionalidades e agências dos trabalhos de artes contemporâneas que envolvem a participação. Objetos e pessoas se encontram simultaneamente, incorporam histórias e coautorias aos processos, tornando indistinguível produção e apropriação.

No sentido inverso (ou simétrico), Sansi também discute de que maneira antropólogos podem repensar seu trabalho - procedimentos, alcances, resultados - a partir dos processos de artistas. A etnografia sempre foi relacional, permeada por hospitalidade e troca de dons. Sansi sublinha os acasos da etnografia, permitindo experimentação e bricolagem a partir das contingências. Defende que o encontro no trabalho de campo seja pensado não como um método, mas uma estética de colaboração e participação. O processo artístico poderia ser um modelo para a pesquisa antropológica também para desestruturá-la, trazer outros elementos para sua manufatura e retirá-la da necessidade de produzir um discurso coerente.

O livro se conecta à corrente, ligada a autores como George Marcus (2010, 2014), que defende a antropologia como construtora das realidades que estuda, ao invés de representar uma já existente. Uma abordagem performativa e transformativa do campo social em que os "dados" são produzidos a partir de disparadores, como na moldura artística - o que se denomina "conceitualismo etnográfico" (Ssorin-Chaikov, 2013). O campo é pensado como um evento do encontro e a etnografia como um dispositivo, que não representa realidades preexistentes, mas performa mundos possíveis, aproximando experimentação artística e ciência.

Há no livro, porém, uma leitura propositiva da antropologia que caberia ser problematizada. O objetivo de autores como Mauss (2003) não é fomentar a dádiva na sociedade da mercadoria. No texto de Sansi, o ofício de traçar relações (próprio da antropologia) se confunde com o atributo, dos trabalhos 
participativos, de fomentar relações. O autor embaralha, em algumas passagens, referências de seus interlocutores (artistas), teoria antropológica e sua própria avaliação sobre o potencial transgressivo das duas produções. Caberia pensar os equívocos do intercâmbio de conceitos e práticas entre arte e antropologia e como são traçados os limites de seus campos.

Do projeto We Can Xalant - uma caravana que convida à troca de experiências e que pode ser posteriormente disposta em uma exposição, documentada ou metamorfoseada em outros formatos - capa do livro, partem outras interessantes questões. Sansi interroga sobre o papel disruptivo da dádiva nos movimentos artísticos ou se isso é facilmente cooptado por forças da mercadoria. Interessa pensar outros elementos decorrentes da teoria da dádiva maussiana - as obrigações, as hierarquias, as práticas e regras do mercado de arte, a formação e legitimação de carreiras profissionais e a construção de autorias. A agência do trabalho, tanto na arte como na antropologia, pode estar distribuída, mas sob controle direto e assinatura que se perpetua no tempo, reservando certa ambiguidade aos ideais da participação.

\section{Referências}

BOURRIAUD, N. A estética relacional. São Paulo: Martins Fontes, 2009.

GELL, A. Art and agency: an anthropological theory. Oxford: Clarendon Press, 1998.

MARCUS, G. Contemporary fieldwork aesthetics in art and anthropology: experiments in collaboration and intervention. Visual Anthropology, v. 23, n. 4, 263-277, 2010.

MARCUS, G. Prototyping and contemporary anthropological experiments with ethnographic method. Journal of Cultural Economy, v. 7, n. 4, p. 399-410, 2014.

MAUSS, M. Ensaio sobre a dádiva: forma e razão da troca nas sociedades arcaicas. In: MAUSS, M. Sociologia e antropologia. São Paulo: Cosac Naify, 2003. p. 183-314.

SSORIN-CHAIKOV, N. Ethnographic conceptualism: an introduction. Laboratorium, v. 5, n. 2, p. 5-18, 2013. 